\title{
UPAYA MENINGKATKAN KREATIVITAS SISWA PADA PEMBELAJARAN IPA BERBASIS STEM (Sciences, Technology, Engineering and Mathematics) PADA MATERI ENERGI DAN DAYA LISTRIK.
}

\author{
Nuraini \\ nurainieni624@gmail.com
}

\begin{abstract}
Abstrak
Rendahnya kreativitas siswa dalam melakukan praktikum dan rendahnya hasil belajar peserta didik kelas IXG SMP N 1 Rembang menjadi permasalahan yang harus diseleseikan. Penelitian ini bertujuan untuk meningkatkan hasil belajar dan kreativitas siswa pada pembelajaran IPA berbasis STEM (Sciences, Technology, Engineering and Mathematics) pada materi energi dan daya listrik. Penelitian ini merupakan penelitian tindakan kelas dengan subyek penelitian adalah siswa kelas IXG SMP Negeri 1 Rembang Semester Ganjil Tahun Pelajaran 2019/2020 sebanyak 32 orang. Metode penelitian menggunakan dua siklus yng masing masing siklus terdiri dari empat tahap, yaitu perencanaan (planning), tindakan (doing), pengamatan (observation) dan refleksi (reflection). Hasil penelitian menunjukkan peningkatan kreativitas dari kurang baik tahap pra siklus, cukup baik pada siklus I dan baik pada siklus II. Hasil belajar pada materi energi dan daya listrik dengan menggunakan metode pembelajaran STEM dari pra siklus ke siklus I mengalami peningkatan 47,4\% dan dari siklus I ke siklus II mengalami peningkatan 19,4\%. nilai rata-rata klasikal dari pra siklus 69 , siklus I dengan nilai 78 menjadi $81,41 \%$ di siklus II dan Kriteria Ketuntasan Belajar (KKM) mengalami peningkatan dari $26,90 \%$ pada pra siklus, $57,70 \%$ pada siklus I menjadi $80,80 \%$ pada siklus II. Kreativitas siswa pada materi energi dan daya listrik dengan menggunakan metode STEM dari tahap pra siklus, siklus I sampai siklus II pada kondisi fleksibilitas, kelancaran, elaborasi dan keaslian dalam belajar mengalami perubahan dari kurang kreatif menjadi lebih kreatif. Berdasarkan observasi kemampuan aktivitas diskusi kelompok, pada pra siklus, siklus I sampai siklus II mengalami peningkatan.
\end{abstract}

Kata Kunci : Kreativitas, STEM, Energi dan Daya Listrik.

\section{PENDAHULUAN}

Salah satu tujuan penerapan kurikulum 2013 adalah mempersiapkan manusia Indonesia agar memiliki kemampuan hidup sebagai pribadi dan warga negara yang beriman, produktif, kreatif, afektif serta mampu berkontribusi pada kehidupan bermasyarakat. Pada pembelajaran IPA kreativitas seorang siswa sangatlah penting. Menurut Munandar (2009), kreativitas adalah kemampuan untuk menciptakan sesuatu yang baru, baik yang benar-benar merupakan hal baru atau sesuatu ide baru yang diperoleh dengan cara menghubungkan beberapa hal yang sudah ada dan menjadikannya suatu hal baru. Kondisi nyata dilapangan menunjukkan bahwa dalam pembelajaran IPA siswa kurang kreatif dalam praktikum, hal ini ditunjukkan dengan sikap peserta didik pasif dalam kerja kelompok, respon yang negatif, yang hal ini merupakan masalah yang dihadapi peserta didik SMP 1 Rembang. Dengan data ini tentunya dapat menjadikan bahan evaluasi kegiatan pembelajaran oleh sekolah terutama oleh guru yang mengajar. Faktor penyebab rendahnya kreativitas belajar IPA pada peserta didik SMP 1 Rembang adalah sebagai berikut : 1) metode pembelajaran yang kurang tepat, 2) media pembelajaran yang kurang menarik 3) sumber belajar siswa yang terbatas. Upaya yang dapat dilakukan untuk meningkatkan kreativitas pada materi Energi dan Daya Listrik peserta didik kelas IXG SMP N 1 Rembang adalah dengan menggunakan model pembelajaran berbasis STEM (Sciences, Technology, Engineering and Mathematics).

Menurut (Devi, 2018) pada pembelajaran IPA berbasis STEM, salah satu karakteristik yang harus terlihat dalam proses pembelajaran adalah 
proses desain rekayasa atau Engineering Desain Process (EDP). Proses ini melatihkan kemampuan peserta didik dalam memecahkan masalah (problem solving) dalam konteks dunia nyata (real world). Secara umum langkah langkah (EDP) adalah: 1. Identifikasi masalah, bertukar pikiran, merancang, membangun, uji coba, revisi dan berbagi solusi atau komunikasi. Pada pembelajaran IPA berbasis STEM, salah satu karakteristik yang harus terlihat dalam proses pembelajaran adalah proses desain rekayasa atau Engineering Desain Process (EDP). Dalam proses pembelajaran IPA yang sifatnya terpadu hendaknya menumbuhkan keterampilan sains, yaitu keterampilan proses, kterampilan berfikir kreatif dan kritis serta menumbuhkan sifat limiah (Devi, 2018:21). Berdasarkan pendapat (LaboyRush, 2018) tahapan pembelajaran berbasis STEM terdiri dari: refreksi, penelitian,penemuan, aplikasi dan komunikasi. Penelitian ini bertujuan untuk meningkatkan kreativitas siswa pada pembelajaran IPA berbasis STEM pada materi Energi dan Daya Listrik.

\section{Metode Penelitian}

Penelitian dilaksanakan pada semester $1 \mathrm{di}$ SMP Negeri 1 Rembang Tahun Pelajaran 2019/2020. Tindakan Kelas ini dilaksanakan dalam dua siklus. Siklus I dilaksanakan minggu ke-1 bulan Oktober 2019 dan siklus ke II dilaksanakan minggu ke -3 pada bulan Oktober 2019.

Subyek penelitian adalah peserta didik kelas IXG SMP N 1 Rembang dengan jumlah 32 siswa, yaitu 18 laki-laki dan 14 perempuan.

Teknik pengumpulan data dalam penelitian ini terdiri dari: 1) Lembar penilaian hasil belajar: berupa tes tertulis yang berbentuk kuis, untuk mengambil data kuantitatif, 2) Lembar penilaian proses (data kualitatif), yang terdiri dari: a). Lembar kuesioner kreativitas peserta didik terhadap proses pembelajaran, b) Lembar observasi berupa lembar penilaian aktivitas peserta didik dalam kelompok dan c) Dokumentasi foto yang digunakan sebagai laporan yang menggambarkan aktivitas peserta didik selama mengikuti pembelajaran.
Teknik analisis dan pengolahan data yang ditempuh peneliti dalam penelitian ini adalah teknik kuantitatif yaitu dengan menganalisis data hasil tes tertulis pada siklus I dan siklus II, sedangkan data kualitatif dari kuisioner kreativitas siswa, lembar observasi dan dokumentasi perilaku siswa pada siklus I dan siklus II.

Indikator kinerja dalam penelitian ini ada dua aspek, yaitu indikator kuantitatif dan kualitatif. 1) Penelitian ini dikatakan berhasil apabila telah mencapai nilai rata rata klasikal lebih atau sama dengan 80. 2) Adanya perubahan perilaku ke arah positif, yaitu : kreativitas siswa, dan keaktifan siswa dalam kelompok. Menurut pendapat shofia (2019: 90) siklus dalam sebuah penelitian dapat dihentikan jika indikator keberhasilan telah tercapai

Penelitian ini dilaksanakan dalam dua siklus dan pada masing-masing siklus terdiri dari empat tahap, yaitu perencanaan, tindakan, pengamatan dan refleksi. Pada siklus I langkah awal yang dilakukan peneliti adalah menentukan Standar Kompetensi, Kompetensi dasar, RPP, materi, media, Lembar Kegiatan Siswa, instrumen angket kreativitas, jurnal guru, foto dokumentasi. Sebelum tindakan siklus I diadakan tindakan pra siklus dengan memberi tes untuk mengetahui kemampuan pemahaman konsep siswa sebelum diberi tindakan. Pada siklus I peneliti membagi siswa menjadi 6 kelompok, masing-masing kelompok beranggotakan 5 atau 6 siswa. Selama proses melakukan praktikum, peneliti mengamati kreativitas kelompok berdasarkan lembar kerja siswa dari peneliti dan pada tahap terakhir siswa diberi post tes untuk mengetahui hasil belajar dengan menggunakan metode pembelajaran STEM, dan untuk mengetahui kreativitas siswa maka peneliti membagikan angket kreativitas dengan mengamatinya. Dari informasi yang diperoleh pada siklus I maka perlu dilakukan refreksi sehingga dapat diketahui kekurangn siklus I. Dari refreksi kemudian diambil langkah perbaikan yang akan dilakukan pada siklus II dengan tanpa merubah sintak. Pada siklus Iitindakan perbaikan peneliti adalah dengan siswa membuat rancangan sendiri tentang menghemat energi listrik. Pada siklus II peneliti menggunakan media bergerak berupa video tentang menghemat 
energi dan siswa dapat mencari sumber belajar lain dari internet. Selama siswa melakukan praktikum kelompok maka peneliti mengamatinya. Pada tahap terakhir siswa diberi post tes untuk mengetahui hasil belajar dan untuk menunjukkan kreativitas siswa dalam praktikum diberi kesempatan unjuk kerja dan hasilnya menunjukkan lebih baik daripada siklus I dan setelah diberi angket kreativitas lebih baik daripada siklus I.

\section{HASIL PENELITIAN DAN PEMBAHASAN Hasil Tindakan Pra Siklus}

Peneliti melakukan tes pra siklus dengan tujuan untuk mengetahui seberapa besarkemampuan peserta didik dan kreativitas belajar peserta didik tanpa menggunakan model pembelajaran STEM sehingga peneliti bisa melakukan tindakan lebih lanjut yang lebih baik. Pada hasil tes pra siklus menunjukkan bahwa nilai rata-rata klasikal 69\% dan ini menunjukkan kategori kurang. Berdasarkan hasil tes tersebut maka siswa yang dapat mencapai KKM di SMP 1 Rembang yaitu nilai 80 atau $19,23 \%$ sedangkan yang tidak tuntas ada $73,08 \%$. Sedangkan kreativitas peserta didik terhadap pelajaran pada pra siklus pada kondisi fleksibilitas, kelancaran, elaborasi dan keaslian dengan nilai 1,50-2,49 termasuk kategori kurang baik.

\section{Hasil Penelitian Siklus 1}

\section{Proses Pembelajaran Melalui Model Pembelajaran berbasis STEM}

Pada siklus I merupakan tindakan awal dari peneliti untuk mengunakan model pembelajaran STEM. Pada siklus I model pembelajaran STEM terdiri dari lima tahapan pembelajaran yaitu refleksi, penelitian, penemuan, aplikasi dan komunukasi. Pada tahap refleksi pengalaman belajar dari siswa adalah peneliti memberikan pertanyaan bersyarat. Pada tahap yang kedua siswa mencari informasi dan berdiskusi tentang penentuan masalah dan pada tahap yang ketiga siswa mulai menyusun jadwal berdasarkan lembar kerja yang diberikan peneliti, dan pada tahap penerapan siswa menguji rancangan dan pada tahap yang terakhir siswa mengkomunikasikan hasil praktikum. Pada akhir pelajaran diberikan post tes untuk mengetahui hasil tes . Hasil tes pada siklus I terdiri dari hasil tes dan hasil non tes yang berupa angket kreativitas peserta didik yang terdiri dari komponen : Fleksibilitas, Kelancaran, Elaborasi, dan keaslian

\section{Hasil Belajar siklus I}

Pada siklus I pada hasil tes peserta didik dengan nilai rata-rata klasikal 78 masuk dalam kategori cukup. Sedangkan yang dapat mencapai KKM SMP 1 Rembang yaitu nilai 80 hanya $58 \%$ sedangkan yang tidak tuntas ada $42 \%$. Oleh karena itu peneliti perlu melakukan penelitian lebih lanjut yaitu pada siklus II untuk melakukan perbaikan pada siklus berikutnya.

\section{Hasil Perubahan Tingkah Laku Siklus I}

Tingkah laku belajar peserta didik yang berupa data angket kreativitas siswa terhadap pelajaran pada siklus I pada kondisi fleksibilitas, kelancaran,elaborasi dan keaslian dengan nilai 2,503,49 termasuk kategori cukup baik. Dan berdasarkan hasil observasi dilakukan selama pembelajaran berlangsung yang dilakukan ada dua macam: observasi tentang kreativitas siswa dalam diskusi kelompok dalam melakukan praktikum dengan empat aspek yaitu aspek fleksibilitas, kelancaran, elaborasi dan keaslian, sedangkan observasi terhadap peneliti yang dilakukan oleh kolaboran.

Pada aktivitas diskusi kelompok pada aspek fleksibilitas masih banyak kelompok yang pasif dan belum menghasilan gagasan ada 39\%. Pada aspek elaborasi masih banyak kelompok yang dalam mengembangkan gagasan masih kurang dengan nilai 39\%. Pada aspek keaslian yaitu kemampuan dalam menuangkan ide ada 5 kelompok yang masih kurang atau $71 \%$. Pada siklus 1 kegiatan observasi guru yang dilakukan oleh kolaboran tentang cara guru dalam menyampaikan tujuan pembelajaran belum jelas, cara guru dalam menyampaikan materi pelajaran guru dalam kegiatan explorasi untuk memotivasi peserta didik masuk ke kegiatan pembelajaran kurang maksimal dan tentang cara guru dalam penyampaian materi pelajaran sudah urut sesuai dengan tujuan pembelajaran tetapi masih 
ada peserta didik yang kurang perhatian dengan materi yang disampaikan contohnya peserta didik sibuk sendiri, dan ngobrol dengan temannya. Guru dalam pembimbingan berdiskusi dalam praktikum sudah baik tetapi masih ada kelompok yang dalam berdiskusi main sendiri, kurang aktif, kerjasama dengan temannya kurang dan dalam menghargai pendapat temannya kurang maksimal dan guru dalam menyimpulkan pelajaran sudah baik.

\section{Refleksi siklus I}

Berdasarkan hasil pengamatan tes dan non tes pada siklus I dengan menggunakan metode pembelajaran STEM belum berjalan dengan baik. Hasil tes pada siklus 1 nilai rata-rata klasikal menunjukkan 78 dengan ketuntasan 58\% hal ini terjadi peningkatan dari pra siklus yang nilai ratarata klasikal menunjukkan 69 dengan ketuntasan hanya $19,23 \%$. Tetapi jika dilihat dari KKM yang ada pada SMP N 1 Rembang dengan nilai 80 maka belum mencapai harapan,sedangkan pada kreativitas peserta didik dalam menerima pelajaran hanya cukup dan dalam berdiskusi kelompok dalam melakukan praktikum juga masih banyak yang pasif sehingga perlu dilakukan siklus II.

\section{Hasil Penelitian Siklus II

Proses Pembelajaran Melalui Model
Pembelajaran STEM

Pada siklus II merupakan tindakan lanjutan dari siklus I dari peneliti untuk melakukan perbaikan. Pada siklus II model pembelajaran STEM terdiri dari lima komponen yaitu presentasi kelas, kerja tim, skor perbaikan individu dan penghargaan tim. Pada presentasi kelas peneliti menggunakan ceramah diskusi dengan memberikan penugasan pada minggu sebelumnya dan menambahkan media pembelajaran dengan penayangkan video sedangkan pada kerja tim peneliti membagi menjadi enam kelompok dan pada akhir pelajaran diberikan post tes untuk mengetahui hasil tes. Hasil tes pada siklus II terdiri dari hasil tes dan hasil non tes yang berupa angket kreativitas peserta didik yang terdiri dari komponen : fleksibilitas, kelancaran, elaborasi dan keaslian observasi aktivitas diskusi kelompok dan dokumentasi.

\section{Hasil Belajar siklus I}

Hasil tes siklus II menunjukkan bahwa nilai rata-rata klasikal $81,41 \%$ dan ini menunjukkan kategori baik. Berdasarkan hasil tes tersebut maka peserta didik yang dapat mencapai Kriteria Ketuntasan Mengajar ( KKM) SMP N 1 Rembang yaitu nilai $80-100$ adalah $80,77 \%$ sedangkan yang tidak tuntas hanya ada 19,23\%. Dan hal tersebut sudah mencapai harapan.

\section{Hasil Perubahan Tingkah Laku Siklus II}

Kreativitas peserta didik terhadap pelajaran pada siklus II pada kondisi fleksibilitas, kelancaran, elaborasi menunjukkan nilai rata-rata 3,5 - 4,49 termasuk kategori baik. Dan berdasarkan hasil observasi dilakukan selama pembelajaran berlangsung yang dilakukan ada dua macam: observasi tentang kreativitas siswa dalam diskusi kelompok pada praktikum dengan empat aspek yaitu aspek fleksibilitas, kelancaran,elaborasi dan keaslian yang dilakukan oleh peneliti, sedangkan observasi terhadap peneliti yang dilakukan oleh kolaboran tentang cara menyampaikan tujuan pembelajaran, cara guru menyampaikan materi pelajaran, menyampaikan kejelasan isi materi, pembimbingan berdiskusi dalam praktikum, guru dalam menyimpulkan.

Pada siklus II tentang aktivitas kreativitas diskusi kelompok pada aspek fleksibilitas sangat baik ada 2 kelompok dengan bobot nilai 72 atau $41 \%$,baik ada 3 kelompok dengan bobot nilai 84 atau $48 \%$ dan pasif ada 1 kelompok dengan bobot nilai 20 atau 11\%. Pada aspek kerjasama sangat baik ada 2 kelompok dengan bobot nilai 54 atau 34\%, baik ada 3 kelompok dengan bobot nilai 92 atau 9\% dan kurang ada 1 kelompok dengan 15 atau 9\%. Pada aspek menghargai pendapat orang lain sangat baik ada 3 kelompok dengan bobot nilai 84 atau $57 \%$, cukup ada 2 kelompok dengan bobot nilai 48 atau 33\% dan kurang ada 1 kelompok dengan bobot nilai 15 atau 10\%. Pada siklus II kegiatan observasi guru yang dilakukan oleh peneliti tentang 
cara menyampaikan tujuan pembelajaran sudah jelas, cara guru menyampaikan materi pelajaran dalam kegiatan explorasi untuk memotivasi siswa dalam melakukan kegiatan praktikum sudah sesuai. Guru dalam penyampaian materi pelajaran sudah urut sesuai dengan tujuan pembelajaran dan semua peserta didik sudah mempunyai perhatian penuh terhadap materi yang disampaikan oleh guru. dalam penyampaian kejelasan materi isi pelajaran sudah jelas. guru dalam pembimbingan berdiskusi dalam pembimbingan berdiskusi dalam melakukan praktikum sudah baik, peserta didik melakukan kegiatan dengan antusias. Guru dalam menyimpulkan pelajaran sudah baik baik.

\section{Refleksi Siklus II}

Berdasarkan hasil pengamatan tes dan non tes pada siklus II, menunjukkan bahwa hasil tes pada siklus II nilai rata-rata klasikal menunjukkan 81,41 dengan ketuntasan ada $80,77 \%$ dan yang tidak tuntas $19,23 \%$ dengan ini terjadi peningkatan dari siklus 1 yang nilai rata-rata klasikal menunjukkan $78 \%$ dengan ketuntasan hanya 58\%. Pada hasil non tes yaitu untuk mengetahui kreativitas siswa pada pelajaran pada siklus II dalam kategori baik. Selama aktivitas pembelajaran berlangsung pada siklus II dalam berkreativitas untuk berdiskusi kelompok dalam praktikum menjadi lebih aktif. Sedangkan pada hasil observasi kolaboran terhadap peneliti tentang aktivitas guru maka aktivitas guru dalam pembelajaran menjadi lebih baik, sehingga bisa dikatakan penelitian ini berhasil.

Tabel 1. Peningkatan Hasil Belajar melalui Metode Pembelajaran STEM

\begin{tabular}{|c|l|c|c|c|c|c|c|}
\hline No & \multicolumn{2}{|c|}{ Kategori } & \multicolumn{2}{c|}{ Prasiklus } & \multicolumn{2}{c|}{ Siklus I } & \multicolumn{2}{c|}{ Siklus II } \\
\hline & & Bobot Skor & $(\%)$ & Bobot skor & $(\%)$ & Bobot skor & $(\%)$ \\
\hline 1 & Sangat baik & 0 & 0 & 260 & 11,54 & 700 & 30,77 \\
\hline 2 & Baik & 407 & 19,23 & 970 & 46,15 & 1057 & 50 \\
\hline 3 & Cukup & 383 & 19,23 & 383 & 19,23 & 153 & 7,69 \\
\hline 4 & Kurang & 487 & 26,92 & 287 & 15,38 & 207 & 11,54 \\
\hline 5 & Sangat kurang & 507 & 34,62 & 120 & 7,69 & 0 & 0 \\
\hline \multicolumn{2}{|c|}{ Jumlah } & 1783 & 100 & 2020 & 100 & 2117 & 100 \\
\hline & Rata-rata (\%) & \multicolumn{2}{|c|}{356,6} & 404 & & \multicolumn{2}{|c|}{423,4} \\
\hline
\end{tabular}

Berdasarkan tabel 1 maka hasil belajar dari pra siklus ke siklus I mencapai 47,4\%. Pada siklus I ke siklus II mencapai 19,4\%. Sedangkan untuk siswa yang mendapat nilai kategori sangat baik dari $11,54 \%$ menjadi $30,77 \%$. Nilai baik dari $46,15 \%$ menjadi $50 \%$ hal ini mengalami peningkatan Sedangkan nilai cukup mengalami penurunan dari $19,23 \%$ menjadi $7,69 \%$, nilai kurang 15,38 menjadi 11,54 dan nilai sangat kurang dari $34,62 \%$ menjadi $0 \%$. Pada peningkatan hasil belajar tahap pra siklus, siklus 1 dan siklus II dapat dilihat pada grafik 1.

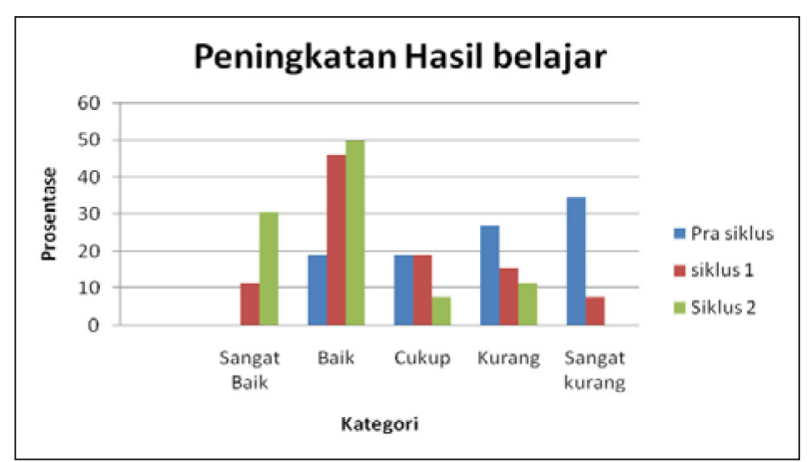

Grafik 1. Peningkatan Hasil Belajar melalui Metode Pembelajaran STEM 
Siswa yang mencapai ketuntasan belajar pada tahap pra siklus mencapai $26,90 \%$, siklus I mencapai 57,70 \% dan pada siklus II ada $80,80 \%$ . Menurut Hal ini dapat dapat disimpulkan bahwa penelitian ini berhasil karena tercapai indikator kinerjanya.

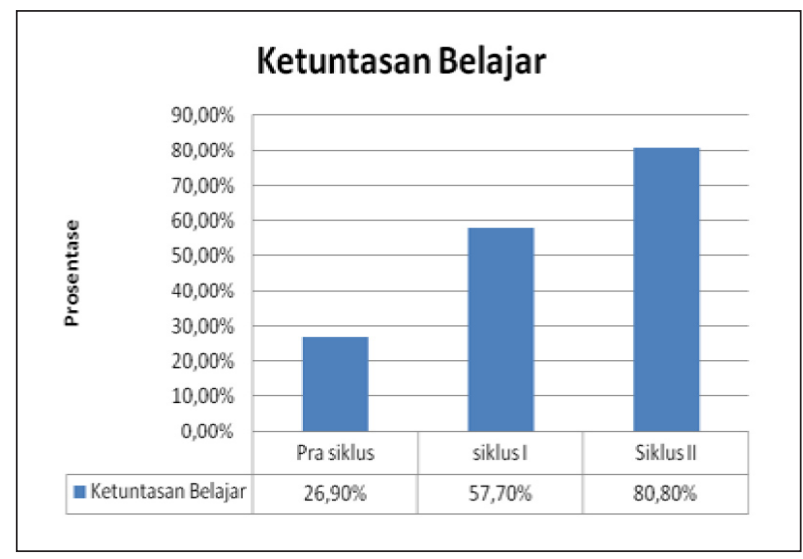

Grafik 2. Ketuntasan Belajar melalui Metode Pembelajaran STEM
Berdasarkan tabel 1, grafik 1 tentang Peningkatan hasil belajar melalui metode pembelajaran STEM pada materi Energi dan Daya Listrik pada siswa kelas IXG Pada SMPN I Rembang mengalami peningkatan $19,4 \%$ dan berdasarkan KKM yang ada di SMP 1 Rembang yaitu 80 maka siswa yang mencapai ketuntasan belajar pada tahap pra siklus mencapai $26,90 \%$, sedangkan pada siklus I mencapai $57,70 \%$ dan pada siklus II ada $80,80 \%$. Menurut siapa?? Hal ini dapat dapat disimpulkan bahwa penelitian ini berhasil karena tercapai indikator kinerjanya.

Tabel 2. Peningkatan Perubahan kreativitas dengan Menggunakan Metode Pembelajaran STEM

\begin{tabular}{|l|c|c|c|c|}
\hline & \multicolumn{4}{|c|}{ Kondisi } \\
\hline & Fleksibilitas & Kelancaran & Elaborasi & Keaslian \\
\hline Prasiklus & 2,47 & 2,43 & 2,42 & 2,38 \\
\hline Siklus I & 3,19 & 3,34 & 3,32 & 2,96 \\
\hline Siklus II & 3,51 & 3,53 & 3,59 & 3,57 \\
\hline
\end{tabular}

Berdasarkan tabel tentang peningkatan perubahan kreativitas dengan menggunakan metode pembelajaran STEM pada materi Energi dan Daya Listrik dapat disimpulkan bahwa terjadi peningkatan perubahan kreativitas dari kurang baik pada pra siklus, menjadi cukup baik pada siklus 1 dan baik pada siklus yang ke II pada materi energi dan daya listrik Kreativitas melalui model pembelajaran STEM

Berdasarkan deskripsi tersebut, maka hipotesis yang diajukan diterima, yakni proses pembelajaran melalui model pembelajaran STEM dapat meningkatkan kreativitas dan hasil belajar pada materi energi dan daya listrik bagi peserta didik kelas IXG semester 1 Tahun Pelajaran 2019/2020.
Pembahasan

Proses Pembelajaran Melalui Model Pembelajaran STEM pada Materi Energi dan Daya Listrik.

Proses pembelajaran dengan melalui model pembelajaran STEM pada materi energi dan Daya Listrik dari siklus I dan siklus II mengalami peningkatan dan sangat cocok digunakan dalam materi energi dan Daya Listrik karena model pembelajarn STEM merupakan model pembelajaran kooperatif. Menurut Ibrahim (2000 :7-10) Pembelajaran kooperatif dilakukan dengan membentuk kelompok kecil yang anggotanya heterogen untuk bekerja sebagai sebuah tim dalam menyelesaikan masalah, tugas, atau mengerjakan sesuatu untuk mencapai tujuan bersama. Menurut pendapat (Devi, 2018:30) Pada pembelajaran menggunakan model STEM dengan materi energi 
dan daya listrik menunjukkan hasil yang lebih baik karena model pembelajaran STEM merupakan suatu pendekatan dimana sains, teknologi, engineering, dan matematika diintegrasikan dengan fokus pada proses pembelajaran pemecahan masalah dalam kehidupan sehari hari. Dengan menggunakan lima tahap pengalaman belajar yaitu: refleksi, penelitian, penemuan, penerapan dan komunikasi siswa lebih tertantang untuk mengemukakan idenya lebih leluasa pada materi energi dan daya listrik dan bisa diterapkan dalam kehidupan sehari hari maka siswa lebih tertarik sehingga mendapatkan hasil yang lebih baik. Menurut Yanuar (2018:5) pembelajaran STEM mengintegrasikan pada penguatan pendidikan karakter dengan nilai-nilai: religius, nasionalis, mandiri, integritas dan gotong royong, sehingga pembelajaran STEM cocok untuk menuju pendidikan abad 21 yang bertujuan untuk mewujudkan cita-cita bangsa, yaitu masyarakat bangsa Indonesia yang sejahtera, bahagia, dengan kedudukan yang terhormat dan setara dengan bangsa lain dalam dunia global, melalui pembentukan masyarakat yang terdiri dari sumber daya manusia yang brkualitas, yaitu pribadi yang mandiri, berkemauan dan berkemampuan untuk mewujudkan cita-cita bangsanya (BSNP, 2010). Pembahasan dalam laporan penelitian tindakan kelas ini meliputi peningkatan hasil belajar dari pra siklus, siklus I dan siklus II, peningkatan perubahan kreativitas dan peningkatan keaktifan peserta didik dalam berdiskusi kelompok dengan menggunakan model pembelajaran STEM.

\section{Peningkatan Hasil Belajar dengan Menggunakan Metode Pembelajaran STEM.}

Peningkatan hasil belajar untuk materi

Energi dan Daya Listrik dengan menggunakan metode STEM, mengalami peningkatan dari pra siklus, siklus I sampai siklus II. Hal ini dikarenakan siswa lebih jelas dalam menguasai materi karena ditunjang dengan adanya pengalaman secara langsung dalam penerapan di kehidupan sehari-hari sehingga siswa mendapatkan hasil belajar yang lebih baik di siklus II jika dibandingkan dengan pra sikkus dan siklus 1. Kemampuan penalaran siswa sangat diperlukan siswa baik dalam pembelajaran fisika maupun dalam kehidupan sehari-hari (Agustina, 2017).

Berdasarkan deskripsi tersebut, maka hipotesis yang diajukan diterima, yakni proses pembelajaran melalui model pembelajaran STEM dapat meningkatkan kreativitas dan hasil belajar pada materi energi dan daya listrik bagi peserta didik kelas IXG semester 1 Tahun Pelajaran 2019/2020.

\section{SIMPULAN}

Berdasarkan hasil penelitian dan pembahasan simpulan dari penelitian ini sebagai berikut:

a. Proses pembelajaran melalui model pembelajaran STEM dapat meningkatkan kreativitas siswa SMP Negeri 1 Rembang klas IXG Tahun Pelajaran 20192020.

b. Hasil belajar pada materi energi dan daya listrik dengan menggunakan metode pembelajaran STEM dari pra siklus ke siklus I mengalami peningkatan 47,4\% dan dari siklus I ke siklus II mengalami peningkatan $19,4 \%$. nilai ratarata klasikal dari pra siklus 69 , siklus I dengan nilai 78 menjadi 81,41 di siklus II dan KKM mengalami peningkatan dari $26,90 \%$ pada pra siklus $57,70 \%$ pada siklus I menjadi $80,80 \%$ pada siklus II.

c. Perubahan tingkah laku pada keatifitas peserta didik pada materi energi dan daya listrik dengan menggunakan metode STEM dari tahap pra siklus, siklus I sampai siklus II pada kondisi fleksibilitas, kelancaran, elaborasi dan keaslian dalam belajar mengalami perubahan dari kurang kreatif menjadi lebih kreatif. Berdasarkan observasi kemampuan aktivitas diskusi kelompok, pada pra siklus, siklus I sampai siklus II mengalami peningkatan. Pada aspek kerjasama peserta didik memiliki kerjasama baik, pada aspek menghargai pendapat orang lain sangat baik.

\section{Saran}

Berdasarkan simpulan hasil penelitian diharapkan guru IPA hendaknya dapat melakukan 
penelitian lebih lanjut mengenai hal serupa dengan memilih metode pembelajaran yang sama dengan materi yang berbeda dan lebih bervariasi untuk mencapai tujuan pembelajaran.

\section{DAFTAR PUSTAKA}

BSNP. (2006), Pengembangan Penilaian. Jakarta. Depdikna.

Devi, P.K., Herliani, E., Setiawan, P., Yanuar, Y., Karyana, S. (2018). STEM. Kementrian Pendidikan dan Kebudayaan SEAMEO Regional Center for QITEP in science.

Desy, A. 2017. Penerapan Pembelajaran Berbasis STEM (Science, Technology, Engineering and Mathematics) Untuk Meningkatkan Kemampuan Control of Variable Siswa SMP Pada Hukum Pascal. Diakses dari URL. https://www.google.com/search?q=j urnal+stem\&rlz=1C1CHBD_idID910ID91 $0 \&$ oq $=$ jurnal + stem $\&$ aqs $=$ chrome $.0 .69 i 59 j$ 016j69i60.6928j0j7\&sourceid $=$ chrome\&ie $=\mathrm{UTF}(8$ September 2020)

Fikri, M. R., Muslim, Purwana, U., Karyaan. (2019, Februari). Upaya Meningkatkan Kreativitas Siswa Dalam Membuat Karya Fisika Melalui Model Pembelajaran Berbasis STEM I Science, Technology, Engineering and Mathematics) padaMateriFluidaStatis. Diakses dari URL. https://ejournal.upi. edu/index.php/WPF/article/view/15771. (8september 2020)

Ibrahim, M. 2000. Pembelajaran Kooperatif. Surabaya, Unesa.

Munandar, U.2009. Pengembangan Kreativitas Anak Berbakat. Jakarta: Rineka Cipta.

Shofia, E. 2019. Mudahnya PTK. Rembang: Perkempulan Inspirassy Sentral Indonesia.

Wiriaatmadja, R. 2008. Metode Penelitian Tindakan Kelas. Bandung: PT. Remaja Rosdakarya.

Yanuar Y, 2018. Energi dan Daya Listrik. Bandung: SEAMEO QITEP. 